\title{
Capital Structure and Financial Performance of Pharmaceutical Companies in Indian Stock Exchange
}

\author{
Tom Jacob ${ }^{1}$ and V.S Ajina ${ }^{2}$ \\ ${ }^{1}$ Assistant Professor, Department of Commerce, Christ College, Irinjalakuda, Kerala, India \\ ${ }^{2}$ Research Scholar, SMS, CUSAT, Kerala, India \\ E-mail: tomjacob9753@gmail.com
}

\begin{abstract}
Capital Structure is an integral and important part of financial management having long term consequences. This paper tries to examine the impact of capital structure on the financial performance of Pharmaceutical companies in India. Capital structure is measured by the Debt Equity Ratio and firm performance as measured by Return on Equity. Regression Analysis is used to analyze the impact of capital structure on the financial performance of the pharmaceutical companies in India. The result indicates that the financial performance has no link with capital structure, which proves the Modigliani and Miller Theory of Capital Structure. The results of this study will provide meaningful insights to the academia and the corporate for better decision making.

Keywords: Capital Structure, Financial Performance, Pharmaceutical Companies
\end{abstract}

\section{INTRODUCTION}

Financing and investment are two key decision-making areas of a firm. The financial manager is concerned with determining the best financing mix or capital structure for a firm in the financing decision. Capital structure is composition or made up of its capitalization and it includes all long term capital resources like loans, reserves, shares and bonds. The relationship between the company's capital structure and financial performance is an important unresolved problem in the field of finance, and has been thoroughly studied both theoretically and empirically. The important lies in the fact that different source of capital have different risk return characteristics. Certain sources are more costly but lesser risky, while others are less costly but more risky. Capital structure decision is important because it affect the financial risk by the company, it also effect the firm's cost of capital, the value of the firm and attitude of the management. The role of capital structure on the performance of the company is to help increase the market price of shares and securities which in turn lead to increase in the value of the firm, protects the business enterprise from over-capitalisation and under-capitalisation; it also helps to minimisation of financial risk. An optimum capital structure enables management to increase the profits of a company in the form of higher return to the equity shareholders, which means increase in earnings per share.

Capital structure refers to the proportion of debt and equity that the firm uses for its finance. In 1958, Modigliani and Miller described what they called capital structure irrelevance. This has been since known as Modigliani \&
Miller theorem, henceforth referred to as MM. They demonstrated that complete debt can be an optimal capital structure, under certain conditions. According to MM, neither capital structure nor dividend policy matter in determining the value of the firm in perfect capital markets. In addition to this seminal work by Modigliani and Miller, other scholars elaborated theories that attempt to explain capital structure in imperfect markets. Modigliani and Miller (1958) proposed the role of the debt in the values of a firm. At first they proposed that the irrelevance of capital structure to firm performance and argued that in a perfect market situation there is no link between firm value and its financing mix. But the introduction of corporation income taxes and transaction costs (Miller 1963) showing that the value of a firm increases with more debt due to the tax shield.

Since Jensen and Meckling (1976) argued about the possibility of influence of capital structure on firm performance, several researchers followed this extension and conducted numerous studies aimed at examining the relationship between financial leverage and firm performance over the last decades. Empirical evidence about that relationship is contradictory and mixed. Many of the researchers are still studying the relationship between capital structure and firm performance, some of them found that there is a negative relation between capital structure and firm performance, while others found a positive relation between capital structure and firm performance. On other hand many papers referred to a significant relation between capital structure and firm performance, while some of them referred to an insignificant relation between capital structure and firm performance.

\section{LITERATURE REVIEW}

The relationship between capital structure and firm value has been the subject of considerable debate. Throughout the literature, debate has centered on whether there is an optimal capital structure for an individual firm or whether the proportion of debt usage is irrelevant to the individual firm's value. The capital structure of a firm concerns the mix of debt and equity the firm uses in its operation. Modigliani and Miller (1958) argued that, under certain assumptions (existence of perfect market and the absence of 
taxes and transaction costs), costs of capital does not affect capital structure. That means the debt in a firm's capital structure does not affect the value of the firm. Later, Modigliani and Miller (1963) modified the irrelevant theory by presenting proof that cost of capital affects capital structure and thus the value of the firm when the assumptions that there are no taxes or transaction costs have been eliminated. They suggested that borrowing give a tax advantage, where the tax deducted from interest results in tax shields, which in turn reduces borrowing costs and maximizes financial performance (Miller, 1977).This requires the firm to make a trade-off between the debt costs and the benefits of using debt.

Khan (2012) analyzed the relationship of capital structure decisions with the performance of firm using 36 engineering firms in Pakistan listed on the KSE for the period of 20032009 using the Panel Econometric Technique, Pooled Ordinary Least Square Regression. The result shows that there is a significant negative relationship with the firm's performance. Salteh, et al (2012) studied the impact of capital structure on firm performance of 28 Iranian companies listed in Tehran Stock Exchange (TSE) over the period of 2005 to 2009. Return on Assets, Return on Equity, Earning Per Share, Market value of equity to the book value of equity and Tobin's Q are used as dependent variables and short-term debt, long- term debt, total debt to total assets and total debt to total equity are used as independent variables of the study. The results of the study indicate that there is a negative relation between capital structure and firm performance. Researchers concluded that firm performance is negatively related to capital structure. Le and Phung (2013) investigated the impact of capital structure on firm performance in all firms listed in Vietnamese Stock Exchange during the period of 2007 to 2011. Return on Assets (ROA), Return on Equity (ROE) and Tobin $\mathrm{Q}$ are used to measuring firm performance. Short-Term Debt, Long Term-Debt and Total Debt Ratios are used for measuring the capital structure. The Result showed that the capital structure has a significant negative impact on firm performance.

Majumdar \& Chhibber (1999) identified the relationship between the levels of debt in the capital structure and performance of Indian firms. The results showed that debt level is negatively related with financial performance of the firms. Vatavu (2014) examined the relationship between capital structure and financial performance of a firm using 196 Romanian companies listed on the Bucharest Stock Exchange as a sample for the period 2003-2010 using Cross Sectional Regression and the result of the study was negative relationship between financial leverage and firm's profitability.

Habimana (2014) evaluate the relationship between capital structure and financial performance through Ordinary Least Squares technique, with the sample of a large crosssectional dataset of firms operating in Africa, Middle East, Asia, Eastern Europe, Russia and China. The finding of the study is that leverage is significant negative to returns and positively to the systematic risk.

Onaolapo and kajola (2010) pointed out the influence of capital structure on financial firm performance of nonfinancial firms listed in Nigerian Stock Exchange in the period of 2001 to 2007. Capital structure is measured by using Debt Ratio (DR), while Return on Assets (ROA) and Return on Equity (ROE) are used to examine firm performance.

They found that the capital structure has a significant negative impact on financial firm performance. Robert OukoObonyo (2017) examined the impact of capital structure on the financial performance of 30 companies listed in the Nairobi Securities Exchange. They identified that there is a weak positive relationship between capital structure and financial performance of the listed companies. Chunhua and Song (2013) explores the impact of capital structure on firm performance of Chinese listed companies in Shanghai and Shenzhen Stock Exchange.

They discovered that there is a negative correlation between company's capital structure and profitability. Anas Ali AlQudah (2017) discussed the relationship between capital structure and financial performance in the firms listed in Abu Dhabi Securities Exchange (ADX) over a period of 2008 to 2015. The result of this study showed that there is a significant relationship between capital structure and financial performance of listed companies in Abu Dhabi Securities Exchange.

Salim and Yardar (2012) observed the relationship between capital structure and firm performance of Malaysia listed companies.ROA, ROE, EPS and Tobin Q are used for the measure of the firm performance. They found that the capital structure impact negatively on the firm's performance.

Mumtaz and Noreen (2013) explained the relationship between capital structure and firm performance in the context of 83 companies selected from KSE 100 index in Pakistan. They suggested that financial performance of firms is significantly affected the capital structure and their relationship is negative in nature.

Thamila and Arulvel (2013) identified the relationship between capital structure and financial performance of 30 listed companies traded in Colombo Stock Exchange for the period of 2007 to 2011. Net Profit Ratio, Return on Capital Employed and Return on Equity are used as indicators for measuring the financial performance. They found that there is a negative relationship between capital structure and firm’s performance.

Rao and Syed (2007) studied the relationship between capital structure and financial performance of Omani firms. The result of the study discovered that there is a negative association between the level of debt and financial 
performance. Despite the above empirical studies reveal a mix of results and can be split into two view points. The first view point argued that there is a positive relationship between capital structure and profitability of the firm (Taub, 1975; Champion, 1999; Ghosh et al., 2000; Hadlock and James, 2002). The second view point indicate that there is a negative relationship between debt level and firm performance (Fama and French, 1998; Simerly and Li, 2000; Vatavu, 2014; Nassar, 2016; Cheruyot, 2015; Khan, 2012). From the above discussions based on the results of empirical literature, it is clear that investigation in the relationship between capital structure and financial performance are inconclusive and requires more empirical works.

\section{OBJECTIVES OF THE STUDY}

1. To analyze the impact of capital structure on financial performance.

2. To evaluate the interrelationship between capital structure and financial performance.

\section{RESEARCH METHODOLOGY}

The study is mainly based on secondary data from 20162020 i.e. Data gathered from the financial statements published by Business Companies. Based on the market capitalization, top five Pharmaceutical companies listed in NSE and BSE are selected. Debt Equity Ratio is taken as independent variable and Return on Equity is selected as dependent variable of the study. Regression Analysis was used to analyze the effect of capital structure on the financial performance of selected Indian pharmaceutical companies in India.

\section{LIMITATIONS OF THE STUDY}

This research study concentrate only five pharmaceutical companies in India, hence the findings of this study may not be true for the whole industry.

\section{DEBT-EQUITY RATIO}

The Debt-to-Equity ratio (D/E) indicates the proportion of the company's assets that are being financed through debt. It is a long term solvency ratio that indicates the soundness of long-term financial policies of the company.

If the ratio is increasing, the company is being financed by creditors rather than from its own financial sources which may be a dangerous trend. Lenders and investors usually prefer low debt-to-equity ratios because their interests are better protected in the event of a business decline. A high debt/equity ratio generally means that a company has been aggressive in financing its growth with debt. This can result in volatile earnings as a result of the additional interest expense. Figure 1 represents the debt- equity ratios of various pharmaceutical companies in India.

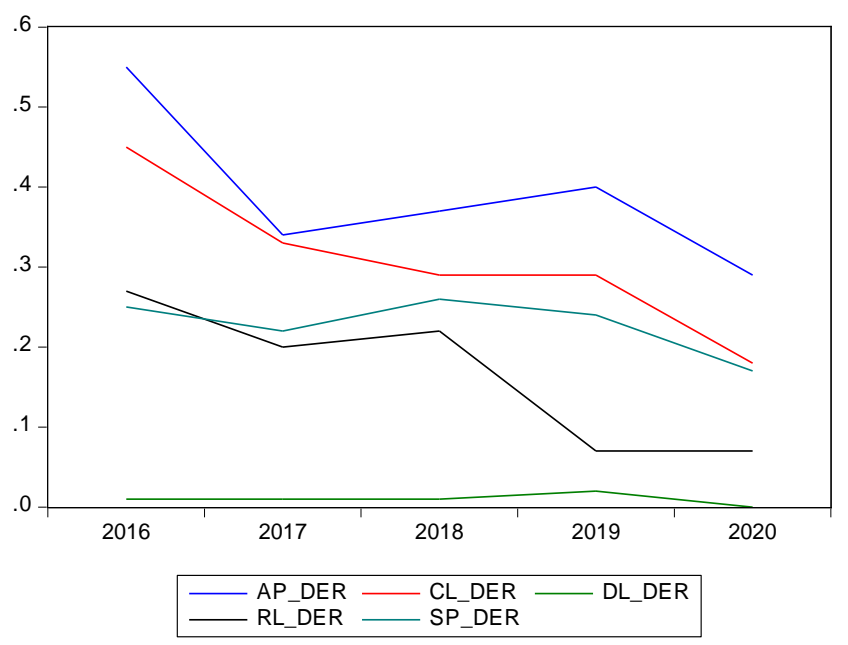

Fig.1Performance of Debt Equity Ratio

TABLE I AVERAGE PERFORMANCE OF DEBT EQUITY RATIO

\begin{tabular}{|l|c|}
\hline \multicolumn{1}{|c|}{ Companies } & Mean \\
\hline Sun Pharmaceutical Industries Ltd. & 0.228 \\
\hline Dr. Reddy's Laboratories & 0.166 \\
\hline Divi's Laboratories & 0.01 \\
\hline Cipla & 0.308 \\
\hline Aurobind Pharma & 0.39 \\
\hline
\end{tabular}

Table I presents the average performance of Debt- Equity Ratio of five pharmaceutical companies. The mean of Debt Equity Ratio is less than 1, showing that all pharmaceutical companies' assets are more funded by equity. It indicate that company having lower leverage and lower risk of bankruptcy. From this analysis (refer Table: I) Divi's Laboratories has better Debt Equity Ratio (0.01) compared to other companies. Aurobind Pharma has higher Debt Equity Ratio (0.39). In the case of Pharmaceutical companies, it is typically favorable for investors to invest in companies with low debt equity ratios. This indicates that all selected companies are favorable for to investment on the basis of Debt - Equity Ratio.

\section{RETURN ON EQUITY}

Return on Equity (ROE) is a measurement of how effectively a business uses equity, or the money contributed by its stockholders and cumulative retained profits to produce income. In other words, an ROE indicates a company's ability to turn equity capital into net profit. A higher ROE suggests that a company's management team is more efficient when it comes to utilizing investment financing to grow their business (and is more likely to provide better returns to investors). A low ROE, however, indicates that a company may be mismanaged and could be reinvesting earnings into unproductive assets.ROE is more than a measure of profit: It's also a measure of efficiency. A 
rising ROE suggests that a company is increasing its profit generation without needing as much capital. It also indicates how well a company's management deploys shareholder capital. Figure 2 represents the Return on Equity of various pharmaceutical companies in India.

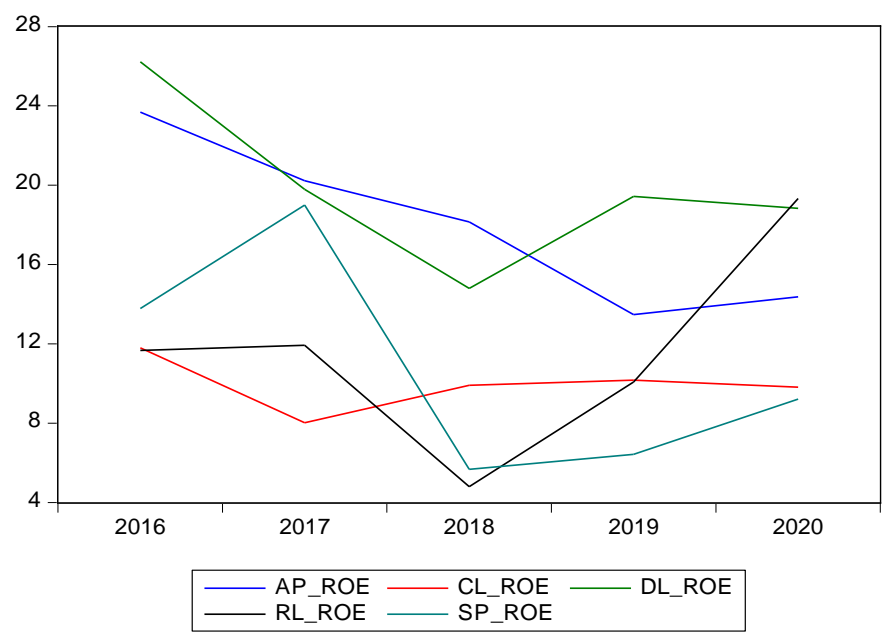

Fig.2 Performance of Return on Equity
TABLE II AVERAGE PERFORMANCE OF RETURN ON EQUITY

\begin{tabular}{|l|c|}
\hline \multicolumn{1}{|c|}{ Companies } & ROE \\
\hline Sun Pharmaceutical Industries Ltd. & 10.818 \\
\hline Dr. Reddy's Laboratories & 11.56 \\
\hline Divi's Laboratories & 19.816 \\
\hline Cipla & 8.338 \\
\hline Aurobind Pharma & 17.982 \\
\hline \multicolumn{2}{|c|}{ Source: Author's calculation } \\
\hline
\end{tabular}

The Table II shows that Divi's Laboratories (19.816) \& Aurobind Pharma(17.982) have the maximum Mean value of $\mathrm{ROE}$ and indicate that their shareholders are making the maximum profits.

It indicates a good utilization of equity capital. Sun Pharmaceutical Industries Ltd.(10.81),Dr. Reddy's Laboratories (11.56) and Cipla (8.338) have lower Return on Equity which indicates that the companies may be mismanaged and could be reinvesting earnings into unproductive assets.

TABLE III IMPACT OF CAPITAL STRUCTURE ON THE FINANCIAL PERFORMANCE OF SUN PHARMACEUTICAL INDUSTRIES LTD

\begin{tabular}{|l|c|c|c|c|}
\hline \multicolumn{1}{|c|}{ Variable } & Coefficient & Std. Error & t-Statistic & Prob. \\
\hline C & 16.40220 & 20.51456 & 0.799540 & 0.4824 \\
\hline SP_DER & -24.49213 & 89.10954 & -0.274854 & 0.8013 \\
\hline R-squared & 0.024563 & Mean dependent var & & 10.81800 \\
\hline $\begin{array}{l}\text { Adjusted R- } \\
\text { squared }\end{array}$ & -0.300583 & S.D. dependent var & & 5.569127 \\
\hline S.E. of regression & 6.351204 & Akaike info criterion & & 6.824340 \\
\hline Sum squared resid & 121.0134 & Schwarz criterion & & 6.668115 \\
\hline Log likelihood & -15.06085 & Hannan-Quinn criter. & & 6.405048 \\
\hline F-statistic & 0.075545 & Durbin-Watson stat & & 1.436668 \\
\hline Prob(F-statistic) & 0.801270 & & & \\
\hline
\end{tabular}

The Table III indicates that the R-squared value is computed to identify the impact of Debt Equity Ratio on Return on Equity. The R-squared value is 0.0245 . This indicates that Debt Equity Ratio is contributed to determine Return on Equity by $2.45 \%$. The remaining $97.54 \%$ of variance with ROE is attributed by other factors which are not considered for this study. The Regression Result shows that Debt Equity Ratio has insignificant relationship with the financial performance of Sun Pharmaceutical Ltd.

Table IV reports the Regression Result to establish the hypothesis that financial leverage is insignificant relationship with the financial performance.

Here the R-squared value is computed to identify the impact of Debt Equity Ratio on financial performance of Dr. Reddy
Ltd. The R-squared value is0.246. This means Debt Equity Ratio is contributed to determine Return on Equity by $24 \%$. The remaining $76 \%$ of variance with ROE is attributed by other factors.

The results shows that there is an insignificant relationship between Debt Equity Ratio and Return on Equity of Dr. Reddy Ltd. It indicates that there is no link between the changes in the Debt Equity Ratio and shifts in the Return on Equity. 
TABLE IV IMPACT OF CAPITAL STRUCTURE ON THE FINANCIAL PERFORMANCE OF DR. REDDY'S LABORATORIES LTD.

\begin{tabular}{|l|c|c|c|c|}
\hline \multicolumn{1}{|c|}{ Variable } & Coefficient & Std. Error & t-Statistic & Prob. \\
\hline C & 16.26250 & 5.288582 & 3.075022 & 0.0543 \\
\hline RL_DER & -28.32833 & 28.58902 & -0.990882 & 0.3948 \\
\hline R-squared & 0.246581 & Mean dependent var & & 11.56000 \\
\hline $\begin{array}{l}\text { Adjusted R- } \\
\text { squared }\end{array}$ & -0.004559 & S.D. dependent var & & 5.206717 \\
\hline S.E. of regression & 5.218572 & Akaike info criterion & & 6.431499 \\
\hline Sum squared resid & 81.70049 & Schwarz criterion & & 6.275274 \\
\hline Log likelihood & -14.07875 & Hannan-Quinn criter. & & 6.012207 \\
\hline F-statistic & 0.981846 & Durbin-Watson stat & & 1.625900 \\
\hline Prob(F-statistic) & 0.394790 & & & \\
\hline
\end{tabular}

TABLE V IMPACT OF CAPITAL STRUCTURE ON THE FINANCIAL PERFORMANCE OF DIVI'S LABORATORIES LTD.

\begin{tabular}{|c|c|c|c|c|}
\hline SquaresVariable & Coefficient & Std. Error & t-Statistic & Prob. \\
\hline C & 19.51100 & 3.956841 & 4.930954 & 0.0160 \\
\hline DL_DER & 30.50000 & 334.4141 & 0.091204 & 0.9331 \\
\hline R-squared & 0.002765 & Mean dependent var & & 19.81600 \\
\hline Adjusted R-squared & -0.329647 & S.D. dependent var & & 4.101394 \\
\hline S.E. of regression & 4.729329 & Akaike info criterion & & 6.234618 \\
\hline Sum squared resid & 67.09967 & Schwarz criterion & & 6.078393 \\
\hline Log likelihood & -13.58655 & Hannan-Quinn criter. & & 5.815326 \\
\hline F-statistic & 0.008318 & Durbin-Watson stat & & 1.267327 \\
\hline Prob(F-statistic) & 0.933079 & & & \\
\hline
\end{tabular}

Dependent Variable: DL_ROE Method: Least

Table V shows the Regression Result to establish the hypothesis that Debt Equity Ratio is insignificant associated with the Return on Equity. The R-squared value is 0.0027.That means Debt Equity Ratio is contributed to determine Return on Equity by $0.27 \%$. The remaining $99.72 \%$ of variance with ROE is influenced by other factors. In short there is no association between the changes in the Debt Equity ratio and Return on Equity of Divi's Ltd.

TABLE VI IMPACT OF CAPITAL STRUCTURE ON THE FINANCIAL PERFORMANCE OF CIPLA LTD

\begin{tabular}{|l|c|c|c|c|}
\hline \multicolumn{1}{|c|}{ Variable } & Coefficient & Std. Error & t-Statistic & Prob. \\
\hline C & 8.021741 & 2.282680 & 3.514176 & 0.0391 \\
\hline CL_DER & 6.234607 & 7.133376 & 0.874005 & 0.4464 \\
\hline R-squared & 0.202951 & Mean dependent var & & 9.942000 \\
\hline Adjusted R-squared & -0.062732 & S.D. dependent var & & 1.343194 \\
\hline S.E. of regression & 1.384684 & Akaike info criterion & & 3.777995 \\
\hline Sum squared resid & 5.752046 & Schwarz criterion & & 3.621770 \\
\hline Log likelihood & -7.444987 & Hannan-Quinn criter. & & 3.358703 \\
\hline F-statistic & 0.763885 & Durbin-Watson stat & & 2.423974 \\
\hline Prob(F-statistic) & 0.446444 & & & \\
\hline
\end{tabular}

Dependent Variable: CL_ROE Method: Least Squares

Table VI shows the impact of capital structure on the financial performance of Cipla Ltd. The R-squared value is 0.2029 .

That means Debt Equity Ratio is contributed to determine Return on Equity by $20.29 \%$.
The remaining $79.70 \%$ of variance with ROE is attributed by other factors.

The Regression Result shows that there is an insignificant relationship between Debt Equity Ratio and financial performance of Cipla Ltd. 
TABLE VII IMPACT OF CAPITAL STRUCTURE ON THE FINANCIAL PERFORMANCE OF AUROBIND PHARMA LTD.

\begin{tabular}{|l|c|c|c|c|}
\hline \multicolumn{1}{|c|}{ Variable } & Coefficient & Std. Error & t-Statistic & Prob. \\
\hline C & 6.730601 & 7.330990 & 0.918103 & 0.4263 \\
\hline AP_DER & 28.84974 & 18.33779 & 1.573239 & 0.2137 \\
\hline R-squared & 0.452063 & Mean dependent var & & 17.98200 \\
\hline Adjusted R-squared & 0.269417 & S.D. dependent var & & 4.215082 \\
\hline S.E. of regression & 3.602805 & Akaike info criterion & & 5.690477 \\
\hline Sum squared resid & 38.94061 & Schwarz criterion & & 5.534252 \\
\hline Log likelihood & -12.22619 & Hannan-Quinn criter. & & 5.271185 \\
\hline F-statistic & 2.475082 & Durbin-Watson stat & & 1.612032 \\
\hline Prob(F-statistic) & 0.213721 & & & \\
\hline
\end{tabular}

The Table VII shows that, the R-squared value was 0.45 , which indicate that nearly $45 \%$ of the total variations in the financial performance of Aurobind Pharma Ltd can be attributed to the changes in the value of the Debt Equity Ratio.

The Regression Result shows that there is an insignificant relationship between Debt Equity Ratio and financial performance of Aurobind Pharma LTD.

\section{CONCLUSION}

Deciding capital structure is critical for all business organizations. In today's competitive era, such decisions have a significant role in augmenting returns of firms. The present studyappraises the association between the capital composition and its profitability of selected pharmaceutical companies in India.

The objective of this study was to assess the impact of capital structure on financial performance of selected Pharmaceutical companies in India.

Regression Analysis is used to estimate the relationship between the capital structure and firm performance measured by Debt Equity Ratio and Return on Equity.

The Regression result shows that there is no relationship between capital structure and financial performance of the selected pharmaceutical companies listed at the Stock Exchange market in India.

These results are consistent with the findings of previous studies such as (Miller, 1977) (Modigliani \& Miller, 1963) (Khan, 2012), (Salteh, Ghanavati, Khanqah, \& khosroshali, 2012), (Vătavu, 2016),(Cheruyot, 2015)(Chunhua \& Song, 2013)and (Habimana, 2014).
These results suggest that, like the pioneers of capital structure irrelevance, which the capital structure does not affect the financial performance of the companies.

\section{REFERENCES}

[1] Al-Qudah, A. A. (2017). The Relationship between Capital Structure and Financial Performance in the Companies Listed in Abu Dhabi Securities Exchange: Evidences from United Arab Emirates. Review of European Studies , 1-9.

[2] Champion, D. (1999). Finance: The Joy of Leverage. Harvard Business Review , 19 -22.

[3] Cheruyot, R. (2015). Effect of Capital Structure on Financial Performance of Listed Commercial Banks in Kenya. A Case Study of Kenya Commercial Bank Limited. The Strategic Journal of Business and Change Management , 750-781.

[4] Chunhua, W., \& Song, M. (2013). Relationship between Capital Structure and Performance Evidence Based on Information Technology Industry. Second International Conference on Advances in Computer Science and Engineering (CSE 2013), 330-333.

[5] Fama, F. E., \& French, R. K. (1998). Taxes, Financing Decisions, and Firm Value. Journal of Finance , 819-843.

[6] Habimana, O. (2014). Capital Structure and Financial Performance: Evidence from Firms Operating in Emerging Markets. International Journal of Academic Research in Economics and Management Sciences , 159-166.

[7] Hadlock, C. J., \& James, C. M. (2002). Do Banks Provide Financial Slack? Journal of Finance, 383-420.

[8] Jensen, M. C., \& Meckling, W. H. (1976). Theory of the Firm: Managerial Behavior, Agency Costs and Ownership Structure. Journal of Financial Economics , 305-360.

[9] Khan, A. G. (2012). The Relationship of Capital Structure Decision with Firm Performance: A Study of the Engineering Sector of Pakistan. International Journal of Accounting and Financial Reporting , 305-360.

[10] Le, T., \& Phung, D. (2013). Capital Structure and Firm performance: Empirical Evidence from Vietnamese Listed Firms.

[11] Majumdar, S. K., \& Chhibber, P. (1999). Capital Structure and Performance: Evidence from A Transition Economy on an Aspect of Corporate Governance. Public Choice , 287-305.

[12] Miller, M. H. (1977). Debt and Taxes. Journal of Finance , 261-275.

[13] Modigliani, F., \& Miller, M. H. (1963). Corporate Income Taxes and The Cost of Capital: A Correction. American Economic Review , 433443.

[14] Modigliani, F., \& Miller, M. H. (1958). The Cost of Capital, Corporation Finance, and The Theory of Investment. American Economic Review , 261-297.

[15] Mumtaz, R., Rauf, S. A., Ahmed, B., \& Noreen, U. (2013). Capital Structure and Financial Performance: Evidence from Pakistan (Kse 100 Index). Journal of Basic and Applied Scientific Research , 113119. 
[16] Obonyo, R. O. (2017). The Impact of Capital Structure on Financial Performance of Companies Listed at The Nairobi Securities Exchange in Kenya. International Journal of Economics, Commerce and Management , 185-198.

[17] Onaolapo, A. A., \& Kajola, S. O. (2010). Capital Structure and Firm Performance: Evidence from Nigeria. European Journal of Economics, Finance \& Administrative Sciences , 70.

[18] Raja Nag, C. G., \& C, S. F. (2000). The Pricing of Seasoned Equity Offerings: Evidence from REITs. Real Estate Economics , 363-84.

[19] Rao, N., Al- Yahyaee, K. H., \& Syed, L. A. (2007). Capital Structure and Financial Performance: Evidence from Oman. Indian Journal of Economics \& Business, 6 (1), 1-14.

[20] S, N. (2016). The Impact of Capital Structure on Financial Performance of the Firms: Evidence from Borsa Istanbul. Journal of Business \& Financial Affairs , 1-4.

[21] Salim, M., \& Yardar, R. (2012). Capital Structure and Firm Performance: Evidence from Malaysian Listed Companies. Procedia , Social and Behaviourial Science, 156-166.

[22] Salteh, H. M., Ghanavati, E., Khanqah, V. T., \& Khosroshali, M. (2012). Capital structure and Firm Performance: Evidence from Tehran Stock Exchange. International Proceedings of Economic Development and Research , 225-230. 